\title{
TAX TREATEMENT OF FARMERS IN THE REPUBLIC OF SERBIA
}

\author{
Cvjetana Cvjetković1, Janko Veselinović2 ${ }^{2}$ Ivica Nikolic ${ }^{3}$
}

\section{Summary}

The subject of this paper is the tax treatment of natural persons that perform agricultural activities in the Republic of Serbia. The goal of the paper was to analyse norms related to the most important taxes that burden farmers, to assess their status in the Serbian tax system, as well as to formulate appropriate de lege ferenda propositions. The research showed that in many aspects farmers have privileged tax treatment due to the importance of agriculture in national economy, as well as their number and socialeconomic profile. Apart from the normative method, which was used predominantly, sociological, axiological and comparative methods were also used.

Key words: farmers, property tax, income tax, VAT.

JEL: K34, Q19

\section{Introducton}

Agriculture is an extremely important economic activity and crucial precondition of economic development of any country. Its status is somewhat specific because, apart from the economic, it also has social and ecological importance. However, taxation of agriculture while respecting fairness, efficiency, abundance and simplicity is not an easy task. Moreover, in finance literature there is a standpoint that agriculture is the sector that is very difficult to tax (Rajaraman, 2004).

In order to comprehend the overall support that state provides to natural persons that perform agricultural activities (hereafter referred to as 'farmers'), it is necessary to consider not only subsidies, but also tax expenditures, i.e. 'lost revenues'. Due to the fact that they are less visible than subsidies, without their detailed consideration it

1 Cvjetana Cvjetković, Ph.D., Assistant, University of Novi Sad, Faculty of Law, Dositeja Obradovića Square no. 1, 21000 Novi Sad, Serbia, Phone: +381 63507 373, E-mail: ccvjetkovic@pf.uns.ac.rs.

2 Janko Veselinović, Ph.D., Associate Professor, University of Novi Sad, Faculty of Agriculture, Dositeja Obradovića Square no. 8, 21000 Novi Sad, Serbia, E-mail: veselinovic.janko@gmail.com.

3 Ivica Nikolić, Ph.D., Assistant Professor, EDUCONS University, Vojvode Putnika nn., 21208 Sremska Kamenica, Serbia, Phone: +381 63521 171, E-mail: profilov@gmail.com. 
could be concluded that support to farmers is not enough, i.e. 'ignoring tax concessions leads to an understatement of the real extent of government involvement in agriculture' (OECD, 2006). Despite the fact that 'lost revenues' from agriculture are not too high, because taxes levied on agriculture have small portion in total taxes (Fabris, Pejović, 2012), they must not be ignored.

According to the data collected within the agriculture census in 2012, among enumerated agricultural holdings, $99.5 \%$ are owned by natural persons, while the average economic power of family agricultural holding in 2012 was $4.990 €$ (Cvijanović, Subić, Paraušić, 2014). If, together with the above mentioned, we take into consideration the fact that the number of members and full time employees on agricultural holdings in the Republic of Serbia is 1.44 million, and that $98 \%$ of this number are owners and members of agricultural holdings (Ministry of Agriculture, Forestry and Water Management of the Republic of Serbia, 2013), what implies that Serbia is 'overwhelmingly agrarian country' (Mihailović, Paraušić, Cvijanović, 2012), the importance of reviewing tax treatment of farmers becomes evident. Taking into consideration that revenues from certain taxes that burden farmers (property tax and tax on revenue from agriculture and forestry, i.e. tax on revenue from self-employment) belong to local budgets, it is important to emphasise that way of their regulation also affects the degree of fiscal autonomy of units of local self-government.

The goal of the paper is to analyse and assess tax treatment of farmers in the Republic of Serbia, to point out advantages and disadvantages of legal solutions, to determine their ratio legis and to formulate appropriate de lege ferenda propositions. The basic hypothesis from which we started in our research is based on the premise that Serbian legislator, through tax system, provides the privileged treatment of farmers. In order to confirm that hypothesis, the most important taxes (understood in the narrowest sense), to which farmers are subject, are will be analysed. These are property tax, income tax (tax on revenue from agriculture) and value added tax.

\section{Methods of research}

The subject matter of the paper is approached by using classical methods of research of law. In order to reveal logical content of norms dedicated to the tax treatment of farmers in the Republic of Serbia, the initial method, like in any other research of law, was normative method. Sociological method is used in order to explain social causes of norms and axiological method in order to determine their ratio legis. The application of comparative method was of crucial importance for consideration of legal solutions that exist in comparative law, in order to find the one that is best suited for implementation in the Republic of Serbia.

\section{Property tax}

Given that the property tax is paid on real estate, when reviewing fiscal treatment of farmers, the issues of tax treatment of agricultural land and objects used for agricultural production deserve special attention. 
The property tax is paid on property right on agricultural land, but only for those whose surface is larger than 10 acres (Article 2, paragraph 1, point 1) of the Law on Property Taxes). Amendments of the Law on Property Taxes from 2013 erased the provision that prescribed that the property tax is paid on the difference between the total surface of land and surface of 10 acres, which means that, according to the applicable solution, in case of exceeding the limit of 10 acres, the property tax will be paid on the entire surface of agricultural land, which is not in accordance with on the principle of horizontal equity, and therefore it should be amended. In the context of taxation of agricultural land, a provision of the Law on Property Taxes that prescribes that property tax is paid on possession and use of real estate on which property right holder is not known or is not determined (Article 2, paragraph 1, point 6) of the Law on Property Taxes) is also important. Based on this, taxpayer could be determined, for argument's sake, in case of 'abandoned' agricultural land, which is not registered in the cadastre of real estate or during probate proceedings. Namely, although the tax liability based on the property tax in case of inheritance occurs in the moment of death of a testator, it is possible that up until the determination of an heir, agricultural land is used and in these cases person who uses agricultural land is the payer of property tax.

Personal easement (e.g. usufruct right) and right to lease agricultural land are not subject to property tax. Since large surfaces of agricultural land, especially those publicly owned, are used on the basis of the lease agreement (according to data of the Ministry of Agriculture, Forestry and Water Management from 2012, out of 2,480 million acres of agricultural land enlisted in the Register of Agricultural Holdings, 773,603 acres is leased land, out of which $40 \%$ is publicly owned agricultural land), it is clear that in these cases the property right holder, and not the lessee, is in the role of payer of property tax. However, since publicly owned real estate is exempt from property taxation, regardless of whether it is leased with the purpose of making profit (Article 12, paragraph 1, point 1) of the Law on Property Taxes; Article 12, paragraph 3 of the Law of Property Taxes), it is clear that large surfaces of agricultural land will practically remain untaxed.

With amendments of the Law on Property Tax from 2013, Serbian legislator made a radical turnaround, when it comes to laying down tax base for agricultural (and forestry) land. Tax base is no longer completely devalued amount (five times the amount of annual cadastral income from that land), but its value, determined on the basis of usable surface and average price of square metre of agricultural land in the zone in which it is located. Paying property tax on a completely worthless base could be explained only by social-political reasons, because from the fiscal and economic aspects this solution was not justified. Namely, owing to the base of property tax for agricultural land, units of local self-government were deprived of part of their revenues, which in terms of constant budget deficit is not insignificant. In addition, property tax that burdens agricultural land is tax with the least distorting effects due the fact that the offer of the land is completely inelastic. Considering that taxing goods, apart from land, will automatically mean less these goods, tax on land does not create excess of tax burden (Cohen, Caughlin, 2005). 
Average price of square metre of agricultural land is calculated based on the data from at least three turnovers of agricultural land in the period from 1 January to 20 September of a year prior to the year for which property tax is assessed and paid - current year (Article 6, paragraph 1, point 5) of the Law on Property Taxes). Intention of Serbian legislator was, therefore, to make the market value of an agricultural land as the base of the property tax. Taking into consideration the circumstance that all units of local self-government will not be in possession of data on turnover of agricultural land in each of the zones on their territories, Serbian legislator prescribed that in that cases the relevant factor will be average price of a square metre of agricultural land in border zones, i.e. zones that border with the zone in which there was no turnover, regardless of the local self-government unit to which they belong. However, if border zones also do not register turnover of agricultural land, tax base will be equal to base in a current year (Article 6, paragraph 5, point 8) of the Law on Property Taxes). For example, if on the territory of a unit of local self-government there is no turnover of agricultural land in any of the prescribed zones, for purposes of assessing property tax for 2014 tax base will be equal to the base of the current year, i.e. 2013. This means that the property tax base for agricultural land will be completely devalued, because in the tax year of 2013 it was determined based on cadastral income. The 'old' tax base will be valid until units of local self-government obtain relevant data on turnover of agricultural land. Having in mind the conditions on real estate market in the Republic of Serbia, it is thought that the great number of units of local self-government will be faced with absence of data on turnover, therefore in them, despite changing the way of valuing the tax base, there will be no increase in revenues from property tax on this base. This especially refers to smaller and undeveloped units of local self-governments.

In contrast to built structures, agricultural land is subject to proportional rate (Article 11, paragraph 2, point 2) of the Law on Property Taxes). In the spirit of the fact that the property tax is a local tax, central authority prescribed only the highest allowed rate (up to $0.3 \%$ ), and within this limit local self-governments determine its exact height. Prescribing the flat rate for agricultural land is justified. Otherwise, there would be a possibility for tax evasion in order to avoid higher marginal rates - division of land into a number of parcels. Having in mind that certain local self-government units, contrary to the Law, prescribed zero rate for agricultural land (Cvjetković, 2015), prescribing the minimum rate should be considered.

Although the Law on Property Taxes prescribes relatively wide scope of tax reliefs, in the context of taxation of farmers only few of them are relevant. In order to stimulate taxpayers to use agricultural land efficiently, the Law on Property Taxes prescribes tax exemption for agricultural (and forest) land which is being restored, within 5 years since the commencement of restoration (Article 12, paragraph 1, point 6) of the Law on Property Taxes). While the base of property tax was cadastral revenue, the above mentioned provision was not of greater importance. However, commitment to the concept of the taxation of the market value of agricultural land should lead to its use in the accordance with the concept of 'highest and best use' (Paugam, 1999). 
The Law on Property Taxes has one other, very important, tax relief for farmers. This is tax exemption for objects that are intended and used only for primary agricultural production (Article 12, paragraph 1, point 11) of the Law of Property Taxes). These are objects for storing mechanisation, stalls for live-stock, objects for growing mushrooms, snails, fish, etc. (Article 26, paragraph 2 of the Law on Agricultural Land). In order to achieve tax exemption on this basis, it is necessary to determine whether these objects are exclusively used for primary agricultural production, i.e. it is necessary to carry out on-site inspection. Although the above mentioned solution primarily favours farmers, it cannot be disregarded that it also favours local tax authorities, which are, in that way, spared from all difficulties related to valuation of objects that are used exclusively for primary agricultural production, because they are rarely singly on the market.

Farmers in the Republic of Serbia have the possibility to exercise tax exemption for agricultural land on one more basis. It is exemption of very low-value property that is motivated by social-political and administrative reasons. Namely, property tax on the territory of one unit of a local self-government is not paid by taxpayer when total base for all his real estate on that territory does not exceed 400,000 RSD (Article 12, paragraph 2 of the Law of Property Taxes). Having in mind the average price of a square metre of agricultural land, the importance of this provision is clear, when it comes to agricultural land of smaller surfaces located in the peripheral zones of the undeveloped units of local self-governments. For example, the average price of a square metre of agricultural land for determining property tax for 2014 on the territory of Crna Trava municipality in the fourth zone is 54.90 RSD, in Kuršumlija municipality in the fifth zone is 16.00 RSD, and in Babušnica municipality in the fifth zone only 14.70 RSD. In cases when base of the property tax for agricultural land in tax year, due to lack of data on turnover, is based on cadastral revenue, it is highly likely that, based on the Article 12, paragraph 2 of the Law on Property Taxes, tax exemption right can be exercised. All above mentioned tax exemptions for agricultural land and objects intended for primary agricultural production will not be applied if they are permanently given to other persons for making profit (Article 12, paragraph 3 of the Law on Property Taxes).

The property tax will also not be paid on agricultural land that a taxpayer lends without compensation to a person who was driven out after 1 August 1995, on condition that driven out person and members of his/her household do not earn revenues on some other grounds (Article 12, paragraph 5 of the Law on Property Taxes). Behind this tax exemption lies, primarily, social-political reasons, although economic reasons cannot be disregarded, in cases when taxpayer lends without compensation uncultivated agricultural land.

Comparative analysis points out that the privileged treatment of agricultural land, from the aspect of property tax, is very common solution. For example, in FYR Macedonia (Article 8 of Law on Property Tax) and Bulgaria (Lozev, 2010) agricultural land is completely exempted from taxation, while in Republic of Srpska tax exemption is prescribed for cultivated agricultural land, which serves only for the own agricultural production (Article 9 of Law on Real Estate Tax). There are also solutions (Latvia, EP 2015 (62) 3 (737-749) 
Armenia) that provide privileged treatment of agricultural land through normative value as the base of property tax, which significantly differs from market value, and which is usually calculated based on presumptive revenue from agricultural land (Ganzenko, 2010; Kronbergs, 2010). In financial literature there are stances that, in the field of property tax, it is necessary to review tax reliefs prescribed for agricultural land, since the agricultural sector in most countries already has privileged treatment in terms of income tax, and since such a treatment necessarily means increased tax burden of other sectors of economy (Bahl, Wallace, 2010), i.e. stances that preferential treatment of agricultural land is 'major factor constraining the process by which farming adjusts changing economic and technical conditions and reform' (OECD, 2006).

\section{Tax on revenue from agriculture}

The choice of the base of tax on revenue from agriculture is, certainly, one of the most prominent dilemmas in this area. Confusion exists whether this tax should be conceived as real (factual) or as a presumptive tax. Its solution depends on what is the priority for the legislator: fairness, on one hand, or administrative-technical reasons and political goals, on the other. Although taxing actual revenue earned by performing agricultural activities is, by far, the fairest solution because it is in accordance with the ability to pay principle, it is, also, linked with serious administrative-technical difficulties. Namely, a part of farmers' revenues remains outside tax authorities' reach. This, primarily, includes the revenues earned by selling agricultural products on green markets, as well as revenues that would be earned if products indented for personal use would be sold on the market.

Since 2013 in Serbian tax law there is no longer tax on revenue from agriculture and forestry. It was a tax which was paid on presumptive revenue from the land, i.e. cadastral revenue, except when taxpayers opt to pay tax based on actual revenue, which happened very rarely in practice. Its repeal did not lead to loss of revenues for units of local self-governments (revenue from this tax was completely given to them), since this tax had not been paid at all for years. Namely, tax obligation was absurdly small because revaluation of cadastral revenue has not been done since the middle of the 1990s, in order not to 'irritate' the significant number of the electoral body - farmers (Popović, 2011). Thus, the Serbian legislator 'gallantly' freed farmers from paying tax on revenue from agriculture and forestry on cadastral revenue, because otherwise administrative costs would be higher than collected revenues.

From 2013 revenue from agriculture and forestry is classified as revenue from selfemployment, and therefore in the role of a taxpayer are natural persons - the holders of family agricultural holdings listed in the Register of Agricultural Holdings that keep books (Article 31, paragraph 1; Article 32, paragraph 2 of the Law on Individual Income Tax). The above mentioned provision created confusion in terms of whether all holders of family agricultural holdings become entrepreneurs, i.e. whether all of them have obligation, as entrepreneurs, to keep books. Dilemma was resolved in 2013 prescribing that natural persons who earn revenue from agriculture and forestry achieve 
the status of entrepreneur and have an obligation to keep books only under the following conditions: 1. if a holder of the registered agricultural holding chooses to have a status of an entrepreneur by submitting application to the competent tax authority; 2 . if the registered agricultural holding is taxpayer of VAT (Ministry of Finance of Republic of Serbia - Tax Adminstration, 2013).

Article 85, paragraph 1, point 16) of the Law on Individual Income Tax prescribes that revenue from selling agricultural products earned by holders of agricultural holdings, users of agricultural pension and persons who pay contributions for mandatory social insurance on the basis of decision of tax authority, are not treated as other revenues, in terms of that law, and will not, therefore, be taxed. Following legal provisions, if revenue from selling agricultural products are earned by other persons (e.g. members of agricultural holding), that revenue will be treated as other revenue and they will be taxed on the rate of $20 \%$, with recognition of standard expenditures of $90 \%$.

Having in mind the above mentioned, it is clear that a large number of farmers in the Republic of Serbia will not be obliged to pay the individual income tax. Therefore, despite law amendments, the situation is more or less the same. Farmers in the field of taxing their revenue still have privileged treatment. It is not rare solution, i.e. privileged treatment of farmers in the field of taxation of income is a common occurrence, especially in developing countries (Rajaraman, 2004). Situation is different in developed countries. Some of them (USA, Canada) tax agricultural activities as other activities, i.e. they successfully overcame difficulties related to taxation of actual revenue (Andersen et al., 2002), while others take into account administrative and social-political constraints related to the taxation of actual revenue. For example, in Germany the size and value of an estate is a key factor that determines whether taxpayer will pay tax on actual revenue determined in books or on presumptive revenue determined based on the value of land (Andersen et al., 2002). In Poland only special type of agricultural holdings which perform certain agricultural activities (production in greenhouses and plastic tunnels, fungi production, etc.) are in the system of personal income tax. They pay tax on estimated annual income (which is determined based on area or the number of animals), or on actual income determined in books (Soliwoda, Pawlowska-Tyszko, 2014). Other farmers, like farmers in Serbia, pay only agricultural tax which is kind of property tax (Parlińska, 2008). Therefore, comparative analysis showed variety of solutions in this area. In essence, farmers' income may be determined on the basis of entries in books, simplified accounting records, the size of estate and other methods of estimation (Soliwoda, Pawlowska-Tyszko, 2014).

Not taxing revenues earned by farmers is pronouncedly unfair from the aspect of taxpayers who earned revenue in same amount on some other basis. Therefore, although their economic power is the same, they are taxed completely differently. Considering that taxation of actual revenue is currently not feasible, the solution for this situation could be implementation of lump sum taxing, i.e. taxation of presumptive revenue that would be determined on the basis 'relatively rigid way to some factor or factors that can be more easily verified than income itself' (Rao, 1989). The easiest solution would 
be to revaluate cadastral revenue. At the same time it would be an important step in alleviating the qualitative discrimination of revenues. In financial literature there are viewpoints that the cadastral revenue as the base of tax on revenue from agriculture is a good solution for several reasons. Firstly, due to its height, it encourages development of agriculture and leads to lower prices of agricultural products. Secondly, it does not affect the behaviour of farmers, because it is not paid on actual revenue. Thirdly, the tax on cadastral revenue is an 'old' tax to which taxpayers are accustomed (Begović, et al., 2004). Moreover, it provides certainty in terms of the sum of tax obligation. All of this resulted in fact that taxing based on presumptive revenue is done in many countries of different level of development. Although tax conceived in this way provides relatively modest revenues, the fact that with this tax there is significantly less evasion, when compared to tax based on actual revenue, should not be disregarded (Khan 2001). On the other hand, disadvantages of the tax on revenue from agriculture whose tax base is presumptive revenue, apart from unfairness and poor revenue yield, include its static nature, so its revaluation is necessity.

\section{VAT}

In principle, farmers in the Republic of Serbia are not VAT payers, even in cases when their total turnover is more than $8,000,000 \mathrm{RSD}$. Their entrance into the VAT system is voluntary, i.e. they can choose to pay the VAT by submitting registration application, in which case the obligation to pay the VAT lasts for at least two years (Article 34, paragraphs 5-7 of the Law on Value Added Tax). After the period of two years, the status of VAT payer does not seize by virtue of law, but a taxpayer must submit the appropriate request. Situation is somewhat different when it comes to farmers who have the status of an entrepreneur and who keep books. Namely, they acquire the status of VAT payer if they achieve the total turnover higher than 8,000,000 RSD. However, since they choose freely whether to have the status of an entrepreneur, the willingness to enter the VAT system can be seen in this choice. When they enter into the VAT system, farmers are subject to the same treatments like other VAT payers.

Privileged treatment of farmers is reflected in prescribing reduced rates for certain agricultural products. In financial literature there are stances that prescribing reduced rates for agricultural products results in negative protection of agricultural, i.e. this solution does not make distribution of income more equal, because only urban poor may have gained trough lower food price, but not rural poor (Jonson, 1993), and that pure consumption subsidies are much better solution (Alston et al., 1999).

Serbian farmers that are not in the VAT system have the right to VAT compensation. Namely, VAT payers that purchase agricultural or forestry products and agricultural services from farmers that are not VAT payers, will be discriminated when compared to other taxpayers who purchase the same goods and services from other taxpayers, because they cannot deduct the input tax (since a farmer does not calculate the VAT), from the VAT they owe (Popović, 2011). Therefore, the VAT compensation is recognised for agricultural and forestry goods, as well as agricultural services supplied by farmers 
to VAT payers in the amount of $8 \%$ of the value of received goods and services. VAT payers will in return be able to deduct the VAT compensation as the input tax, providing they paid it to a farmer together with the value of received goods and services (Article 34, paragraphs 1-4 of the Law on Value Added Tax). Taking into consideration the right of a farmer to the VAT compensation on one hand, and voluntary entrance into the VAT system on the other, it is logical that those farmers, who estimate that the VAT they pay on inputs they purchase is higher than the sum of the VAT compensation in the special regime, will choose to enter the VAT system (Ilić-Popov, 2005).

Although they are not in the VAT system and, therefore, they do not have the right to deduction of the input tax, with the VAT compensation, in an indirect way, farmers compensate costs on account of the VAT paid when procuring various inputs, like agricultural machines, fertilisers and the like (Ilić-Popov, 2005). It is important to stress that farmers will not be entitled to the VAT compensation for all goods and services they placed on the market, but only for agricultural goods and services. When determining whether the goods or services can be categorised as agricultural goods, i.e. as agricultural service, the Regulation on Activity Classification is of crucial importance. Having in mind its provisions, agricultural goods are deemed to be products obtained by cultivating plants (grains, fruit, vegetables, etc.), cultivating seedlings, etc., and agricultural services are deemed to be various services in planting crops with compensation (e.g. services of sowing, reaping, pest control, pruning of orchards and vineyards, etc.). In the Regulation on Activity Classification it is stressed that agricultural activities exclude further processing of agricultural products, which is classified in special areas - production of food and tobacco products, production of drinks, except such processing which enables preparation of products for the market (cleaning, sorting, protection against rotting). This would mean that farmers will not be entitled to the VAT compensation if they sell, for example, cottage cheese, brandy, wine, etc. to a VAT payer. VAT compensation is also exempt from the taxable income (Article 9, paragraph 1, point 25) of the Law on Individual Income Tax).

Therefore, farmers in the Republic of Serbia, in terms of VAT, have a privileged treatment, which can be seen in several aspects. With these solutions, as a candidate country for the membership in the European Union, the Republic of Serbia completely follows the rules of the Sixth Directive.

\section{Final remarks}

In order to get comprehensive picture of the support that state provides to farmers, it is necessary to take into account 'lost revenues', i.e. revenues that state loses by prescribing rules that deviate from general regime of taxation. The research confirms the largest part of the basic hypothesis - in tax system of the Republic of Serbia farmers have privileged treatment, except in the area of taxation of agricultural land. This treatment is the result of their role in providing basic life and economic needs, their number and social-economic profile, as well as their average economic power. Therefore, their tax treatment is influenced by social-politic and economic goals, which 
prevail over fiscal goals. However, we should not disregard the fact that the privileged treatment of farmers in some cases is result of administrative constraints.

Serbian legislator made a radical turnaround when it comes to determining tax base of agricultural (and forestry) land, in sense that it is market value. It is important step, not only from fiscal, but also from economic aspect. Taxation of market value of agricultural land will mean more revenues for local budgets, its efficient use, as well as providing a greater degree of equity since market value of agricultural land is one of the indicators of economic power of taxpayers. However, lack of data on turnover of agricultural land in many units of local self-governments on the territory of the Republic of Serbia will lead to the state where concept of taxing market value of agricultural land will not be fully implemented. Therefore, local tax administrations should make efforts in order to find data on turnover of agricultural land. In that sense they should establish closer cooperation with Tax Administration and other subjects (real estate agencies, Register of Real Estate Turnover). When it comes to taxation objects that are intended and used only for primary agricultural production, Serbian system of property taxation still 'favours' farmers. Although it should take a stand that any real estate must be taxed, currently this is acceptable solution because these objects are not singly on the market, so their valuation would be problematic.

Unlike property tax, farmers in the Republic of Serbia in the field of income tax still have privileged treatment, which can be observed in the fact that most of them will not be obliged to pay individual income tax, which is pronouncedly unfair solution, especially when it comes to farmers who are owners of big estate. Having in mind that such solution means lost budget's revenues, it could be treated as form of hidden subsidizing of farmers. Considering that taxing real revenue of farmers is linked to serious administrative-technical difficulties, it is necessary to adopt second best solution - taxation of presumptive revenue. Having in mind the state in the Republic of Serbia, it would be best to use the existing framework - cadastral revenue, i.e. it would be best to conduct its revaluation. Although this would mean investing significant material resources and administrative efforts, it seems the greater challenges for revaluation of cadastral revenue is the lack of political willingness to make structural changes in this area, because from the point of view of fairness, i.e. equality, the existing solution is unsustainable. Full implementation of concept of taxing market value of agricultural land in the future will provide alternative to the revaluation of cadastral revenue, i.e. determined value of agricultural land for the purpose of property taxation could be parameter for determining the amount of presumptive revenue from that land.

Although comparative analysis showed that privileged treatment of farmers in the field of the property tax and VAT is common, due to the importance of agriculture in national economy, non-taxation of revenue generated in this sector is not common. Serbian legislator should be aware of this when finding solutions in this field in the future. 


\section{References}

1. Alston, J., Smith, V., Acquaye, A., Hosseini, S. (1999): Least-Cost CheapFood Policies: Some Implications of International Food Aid, Agricultural Economics, vol. 20, no. 3, pp. 191-201, IAAE, Suite, Milwaukee, USA.

2. Andersen, F., Asheim, L. J., Mittenzwei, K., Veggeland, F. (2002): Taxation of Agriculture in Selected Countries, Norwegian Agricultural Economics Research Institute, Oslo, Norway.

3. Bahl, R., Wallace, S. (2010): A Paradigm for Taxation in Developing Countries, in: Challenging the Conventional Wisdom on the Property Tax (eds. Bahl, R., Martinez-Vazquez, J., Youngman, Y.), pp. 165-210, Lincoln Institute of Land Policy, Cambridge, Massachusetts, USA.

4. Begović, B., Ilić-Popov, G., Mijatović, B., Popović, D. (2004): Reforma poreskog sistema (2), Centar za liberalno-demokratske studije, Beograd, Srbija.

5. Cohen, J., Coughlin, C. (2005): An Introduction to Two Rate Taxation of Land and Buildings, Federal Reserve of Bank of St. Louis Review, vol. 87, no. 3, pp. 359-374, Federal Reserve of Bank of St. Louis, St. Louise, Missouri, USA.

6. Cvijanović, D., Subić, J., Paraušić, V. (2014): Poljoprivredna gazdinstva prema ekonomskoj veličini i tipu proizvodnje u Republici Srbiji, Republički zavod za statistiku, Beograd, Srbija.

7. Cvjetković, C. (2015): Porez na imovinu u statici, doktorska disertacija, Pravni fakultet Univerziteta u Beogradu, Beograd, Srbija.

8. Fabris, N., Pejović, I. (2012): Montenegrin Agriculture: Diagnosis and Policy Recommendations, Economics of Agriculture, vol. 59, no. 4, pp. 657-673, IEP, Beograd, Srbija.

9. Ganzenko, Y. (2010): Armenia, in: European Tax Handbook 2010 (ed. O. van Boeijen-Ostaszewska), pp. 51-62, IBDF, Amsterdam, The Netherlands.

10. Ilić-Popov, G. (2005): Zakon o porezu na dodatu vrednost u Srbiji-komentar zakona i podzakonskih akata, Poslovni zbornik, Beograd, Srbija.

11. Jonson, G. (1993): Role of Agriculture in Economic Development Revisited, Agricultural Economics, vol. 8, no. 4, pp. 421-434, IAAE, Suite, Milwaukee, USA.

12. Khan, M. H. (2001): Agricultural Taxation in Developing Countries: A Survey of Issues and Policies, Agricultural Economics, vol. 24, no. 3, pp. 315-328, IAAE, Suite, Milwaukee, USA.

13. Kronbergs, Z. (2010): Latvia, in: European Tax Handbook 2010 (ed. O. van Boeijen-Ostaszewska), pp. 483-500, IBDF, Amsterdam, The Netherlands.

14. Law on Agricultural Land, Official Gazette of the Republic of Serbia, no. 62/06, 65/08, 41/09.

15. Law on Individual Income Tax, Official Gazette of the Republic of Serbia, no. 
24/01, 80/02, 80/02, 135/04, 62/06, 65/06, 31/09, 44/09, 18/10, 59/11, 91/11, 7/12, 93/12, 114/12, 47/13, 48/13, 108/13, 57/14.

16. Law on Property Tax, Official Gazette of the Republic of Macedonia, no. 61/04, 92/07, 102/08, 35/11, 53/11, 84/12.

17. Law on Property Taxes, Official Gazette of the Republic of Serbia, no. 26/01, Official Gazette of FRY, no. 42/02, Official Gazette of the Republic of Serbia, no. 80/2002, 80/2002, 135/04, 61/07, 5/09, 101/10, 24/11, 78/11, 57/12, 47/13, 68/14.

18. Law on Real Estate Tax, Official Gazette of Republic of Srpska, no. 110/08, 118/09.

19. Law on Value Added Tax, Official Gazette of the Republic of Serbia, no. 84/04, 86/04, 61/05, 61/07, 93/12, 108/13, 6/14, 68/14.

20. Lozev, K. (2010): Bulgaria, in: European Tax Handbook 2010 (ed. O. van Boeijen-Ostaszewska), pp. 137-152, IBDF, Amsterdam, The Netherlands.

21. Mihailović, B., Paraušić, V., Cvijanović, D. (2012): Backwardness of Serbian Rural Areas in Terms of Global Crisis, Economics of Agriculture, Vol. 59 (special number), pp. 344-349, IEP, Beograd, Srbija.

22. Ministry of Agriculture, Forestry and Water Management of the Republic of Serbia (2013): Strategija poljoprivrede i ruralnog razvoja Republike Srbije (2014-2024.), Beograd, Srbija.

23. Ministry of Finance of the Republic of Serbia - Tax Administration (2013): Obaveštenje $u$ vezi oporezivanja registrovanih poljoprivrednih gazdinstava $u$ 2014. godini, Beograd, Srbija.

24. OECD (2006): Taxation and Social Security in Agriculture, Paris, France.

25. Parlińska, A. (2008): Legal Aspects of Polish Tax and Social Security in Agriculture, Aestimum, vol. 65, no. 53, pp. 75-87, Firenze University Press, Florence, Italy.

26. Paugam, A. (1999): Ad Valorem Property Taxation and Transition Economies, World Bank, Washington D.C., USA.

27. Popović, D. (2011): Poresko pravo, Pravni fakultet Univerziteta u Beogradu, Beograd, Srbija.

28. Rajaraman, I. (2004): Taxing Agriculture in a Developing Country: A Possible Approach, World Bank, Washington D.C., USA.

29. Rao, M. (1989): Taxing Agriculture: Instruments and Incidence, World Development. vol. 17, no. 6, pp. 809-823, Pergamon, Oxford, United Kingdom.

30. Regulation on Activity Classification, Official Gazette RS, no. 54/10.

31. Soliwoda, M., Pawlowska-Tyszko, J. (2014): Agricultural Taxation in Poland Vs Solutions in Selected EU Countries, Economic Science for Rural Development Conference Proceedings, Jeglava, Latvia, no. 33, pp.99-107. 


\title{
PORESKI TRETMAN POLJOPRIVREDNIKA U REPUBLICI SRBIJI
}

\author{
Cvjetana Cvjetković, ${ }^{4}$ Janko Veselinović ${ }^{5}$, Ivica Nikolic ${ }^{6}$
}

\begin{abstract}
Rezime
Predmet analize ovog rada je poreski treman fizičkih lica koja obavljaju poljoprivrednu delatnost u Republici Srbiji. Cilj rada je da se, kroz analizu zakonodavstva, ukaže ne prednosti $i$ nedostatke normi koje se odnose na najznačajnije poreze koji terete poljoprivrednike, da se oceni njihov položaj u srpskom poreskom sistemu, kao i da se formulišu odgovarajući predlozi de lege ferenda. Istraživanje je pokazalo da u mnogim aspektima poljoprivrednici imaju privilegovani poreski tretman zbog važnosti poljoprivrede za nacionalnu ekonomiju, kao i zbog njihove brojnosti i socio-ekonomskog profila. Osim normativnog metoda, kao najvažnijeg, u radu je korišćen i sociološki, aksiološki i komparativni metod.
\end{abstract}

Ključne reči: poljoprivrednici, porez na imovinu, porez na dohodak, PDV.

4 Asistent Dr Cvjetana Cvjetković, Univerzitet u Novom Sadu, Pravni fakultet, Trg Dositeja Obradovića 1, 21000 Novi Sad, Srbija, Telefon: +38163507373, E-mail: ccvjetkovic@pf.uns.ac.rs.

5 Vanredni profesor Dr Janko Veselinović, Univerzitet u Novom Sadu, Poljoprivredni fakultet, Trg Dositeja Obradovića 8, 21000 Novi Sad, Srbija, E-mail: veselinovic.janko@gmail.com.

6 Docent Dr Ivica Nikolić, EDUCONS Univerzitet, Vojvode Putnika bb, 21208 Sremska Kamenica, Srbija, Telefon: +38163521171, E-mail:profilov@gmail.com.

EP 2015 (62) 3 (737-749) 